\title{
Impact of Front Line Demonstration on Chickpea to Meet the Deficit Pulse Availability in Malwa Plateau and Central Plateau Region of India
}

\author{
Ishwar Singh $^{1^{*}}$, D.S. Tomar ${ }^{2}$, M.V. Mahajan ${ }^{3}$, D.S. Nehte ${ }^{3}$, \\ Lakhan Singh $^{4}$ and H.P. Singh ${ }^{5}$ \\ ${ }^{1}$ KVK, Pal, Jalgaon, M.S., India \\ ${ }^{2}$ Agronomy, KVK Ujjain RVSKVV, Gwalior, India \\ ${ }^{3} S M S, K V K$, Pal, Jalgaon, M.S., India \\ ${ }^{4}$ ATARI-Pune, Zone-VIII, India \\ ${ }^{5}$ Directorate of Extension, RVSKVV, Gwalior, India \\ *Corresponding author
}

\section{A B S T R A C T}

\section{Keywords}

Front Line

Demonstrations,

Potential yield,

Chickpea, Technology

index

Article Info

Accepted:

20 January 2018

Available Online:

10 February 2018
Front Line demonstrations (FLDs) are the important extension techniques to convince the farmers about latest farm technologies. The present study was conducted to assess the impact of frontline demonstrations Bengal gram crops conducted in the Central Plateau Region of Maharashtra and the Malwa plateau of Madhya Pradesh. Study revealed that improved cultivation practices comprised under FLDs viz., recommended varieties, seed rate, timely sowing and plant protection technology resulted in increase in yield in gram crop over the check plots. Technology gaps, extension gaps and technology indices were calculated to analyse the performance of these front line demonstrations at farmers' fields which indicate the role of extension functionaries to act in a mission mode to fill the gaps and make the region self-sufficient in pulses.

\section{Introduction}

Pulse-based food is an important source of dietary protein and essential minerals. On an average at the global level, pulses share $5 \%$ of the total protein consumption but their contribution in several developing countries ranges from 10 to $40 \%$. The World Food Programme for instance includes 60 grams of pulses in its typical food basket, alongside cereals, oils, sugar and salt. However, the global per capita availability of pulses declined from $9.5 \mathrm{~kg}$ in the sixties to around 6 $\mathrm{kg}$ in mid-2000 and marginally increased since then. Historically India is the largest producer, consumer and importer of pulses. Pulses are a good and chief source of protein for a majority of the population in India. Protein malnutrition is prevalent among men, women and children in India. Pulses contribute $11 \%$ of the total intake of proteins in India (Reddy, 2010). In India, frequency of pulses consumption is much higher than any other source of protein, which indicates the importance of pulses in 
their daily food habits. Keeping the cheapest source of protein, it is important to increase pulses production to increase balanced diet among the socially and economically backward classes.

Dry areas which cover $41 \%$ of the earth's surface are home to over 1.7 billion people and majority of them are poor. About $16 \%$ of the population lives in chronic poverty, particularly in marginal rainfed areas. With climate change and depleting natural resources, we need to focus on that climate smart crops which require not only less inputs but also contribute positively to soil health and environments. Pulses contribute greatly to the sustainability of the prevailing cropping systems; and they need to be main stream in cereal-based production systems where ground water depletion is fast and soil health is becoming a serious issue. Cultivation of pulses requires ten times less water than producing the same quantity of animal meat. Pulses not only fix atmospheric nitrogen to the extent of $70-210 \mathrm{~kg} / \mathrm{ha}$ but also lower carbon footprint because of low carbon emission and higher carbon sequestration. Global production of pulses has increased from 42 million tons in $70 \mathrm{~s}$ to 72 million tons at present, thanks to both area increase from 63 to 80 million ha and productivity enhancement from $670 \mathrm{~kg} / \mathrm{ha}$ to the present level of 905 $\mathrm{kg} / \mathrm{ha}$ which is still low considering the potential of these crops.

\section{Constraints in pulse production}

Even with the best efforts, pulses production and productivity has been stagnant. Due to the low productivity-low input nature, pulses are grown as residual/alternate crops on marginal lands after taking care of food/income needs from high productivity high input crops like paddy and wheat by most farmers. Also, they grow as rainfed crops with little or no modern yield enhancing inputs. The low priority accorded to pulse crops may be $\mathrm{r}$ elated to their relatively low status in the cropping system. As a crop of secondary importance, in many of these systems, pulse crops do not attract much of the farmer's crop management attention.

Abiotic constraints cause high degree of risk in pulses production. More than $87 \%$ of the area under pulses is presently rainfed. The mean rainfall of major pulse growing states such as Madhya Pradesh (MP), Uttar Pradesh (UP), Gujarat and Maharastra is about 1,000 $\mathrm{mm}$ and the coefficient of variation of the rainfall is $20-25 \%$. Moisture stress is the oftcited reason for crop failures. Terminal drought and heat stress results in forced maturity with low yields. Drought stress alone may reduce seed yields by $50 \%$ in the tropics, Saxena et al., (2000).

\section{Materials and Methods}

The present study was conducted by the Krishi Vigyan Kendra, Pal, Jalgaon of Maharashtra and KVK Ujjain, of Madhya Pradesh continuously for six consecutive years (200910 to 2014-15) to assess the impact of improved technology of chickpea under real farm situations. These two regions represent soybean dominated area having almost identical soil types and rainfed eco-system under soybean - wheat and soybean chickpea cropping system. The aim of the FLDs was to demonstrate the impact of research emanated production technologies that of improved varieties, seed treating chemicals, Integrated Nutrient management, Integrated pest Management and strategies to economize water application and prevent the crop from abiotic stress particularly frost in the month of December and January and high temperatures at seed filling to maturity stages. The speedy adoption of improved technologies and innovations are the most important tools for enhancing the agricultural production at faster 
rate and hence it is a crucial aspect under innovation diffusion process. The main objective was to demonstrate the productivity potential and profitability of the latest improved production technology in real farm situation under different and aberrant weather situations to address the following problems identified in PRA.

Use of high seed rate.

Lack of concept of crop rotation.

Heavy reliability on traditional varieties coupled with use of exotic strain of Kabuli (Dollar Chana) from Mexico causing heavy loss due to soil borne fungal pathogens, particularly collar rot, fusarium, dry root rot and depleting soil fertility.

Low or no use of organic matter and biofertilizers.

Imbalance use of fertilizers in pulses. Potassium and Sulphur are the most neglected nutrients.

Faulty method and improper time of fertilizer application.

Lack of intercultural operations by cultivators adopting chemical weed control.

The Integrated crop management approach (full package) was demonstrated to the farmers through mutual sharing of inputs in FLD trials included the components like improved variety, seed rate, spacing INM and IPM. Only the critical inputs and technical management was provided by the KVKs and the rest input was borne by the farmer. The data generated, in full package technology was utilized for calculating the technological index, technology and extension gaps using the formulae given by Kadian et al., 1997 Samui et al., 2000, to assess the impact of scientific technology among the farmers and its horizontal spread.

Technological Gap $=$ (Potential yieldDemonstration yield)

Extension gap $=($ Demonstration yield-Farmers yield)

Technology index $=$ P-D $/ \mathrm{P} * 100$.

The yield increase in demonstrations over farmers' practice was calculated by using the following formula:

$\%$ Yield increase over farmers' practice $=$ Demonstration average plot yield-farmers average plot yield/Farmers average plot yield

\section{Results and Discussion}

There is a general feeling that pulses (C-3 plants) suffer from inherently low yield potential and are a physiologically inefficient group of plants compared to cereals (C-4 plants) such as sorghum and maize. However Aggarwal et al., (1997), reviewed the comparative advantages of C-3 and C-4 group of plants and argued that C-3 and C-4 plants seem to compete on fairly even terms in hot dry environments. The fact that C-3 plants usually do better in cool climates suggests that C-3 plants are better for rabi season.

\section{Grain yield}

Data presented in Table 1(a) and 1(b) revealed that transfer of improved farm technology under frontline demonstrations (FLDs') in chickpea resulted in invariably higher grain yield in both the states. The yield in farmers plot and demonstration plot on an average in Maharashtra was 17.6 and 23.9 quintals/ha and in Madhya Pradesh was 10.5 and 15.3 $\mathrm{qt} / \mathrm{ha}$, thus showing an increase of 35.7 and 45.7 percent, respectively. This may be 
attributed to the adoption of recommended agro technologies in FLDs' during study period. This could be better justified vide the facts as illustrated by Reddy,2006 that farmers have been applying sub-optimal doses of fertilizers, pesticides and number of irrigations for pulses after meeting the requirements of wheat, vegetable and other crops. In chickpea, most farmers applied $40 \mathrm{~kg} / \mathrm{ha}$ urea. To address the problem of wilt and pod borer, farmers used pesticides. Only occasionally some farmers applied farm yard manure at the rate of $2 \mathrm{t} / \mathrm{ha}$. The improved variety of chickpea variety (Vijay and JG-130) recorded a yield increase of ranging from 35 to 45 per cent I different years of study over local varieties. Similar trend I yield levels have been reported by Sagar Chandra (2004), Sharma et al., (2012) and Choudhary (2009b) by the use of recommended agro-technologies in FLDs'.

\section{Technological and extension yield gaps and technological index}

Technological yield gaps affecting yield in chickpea on an average in Madhya Pradesh was 19.3 qt as against 7.6 qt in Maharashtra. This is indicative of the fact that the possibilities of increasing the yield are more promising in the former case. Moreover, this also indicates that the most promising technologies have not yet been adopted by the farmers due to various constraints or few technologies may have become redundant. In Madhya Pradesh the traditionally chickpea producing pockets have changed in to wheat and other crops due to increase in the irrigation facilities whereas in Maharashtra the Vidharbha region is still the most arid region and hence the technologies once showcased have a better impact on farmers field. Technological gaps appear even if the FLDs' are conducted under the strict supervision of farm scientists on the farmers' fields. This may be attributed mainly due to lack of irrigation infrastructure, ill distribution of rainfall, variation in soil fertility cultivation on marginal lands, non-congenial weather conditions local specific crop management problems faced in order to harness the yield potential of specific crop cultivars under demonstration plots (Sagar Chandra, 2004; Vaghasia et al., 2005; Choudhary et al., 2009b). Trends can be seen more apparently in Figure 1.

Higher extension yield gap in the present study (Table 2 and 3 ) indicates that there is a strong need to aware and motivate the farmers for adoption of improved farm technologies in chickpea over existing local practices, more so in Maharashtra where the average extension yield gap is $6.2 \mathrm{q} / \mathrm{ha}$ as compared to 4.8 in Madhya Pradesh. Refinement in the local farmers' practices for higher adoption of location specific generated farm technology for sustaining crop productivity is another option open for the research scientists. Extension yield gaps are the indicators of lack of awareness for the adoption of improved farm technologies by the farmers Kadian et al., (1997).

Technology index shows the feasibility of the evolved technology on the farmer's field under existing agro climatic situations. In the present study the technological index of chickpea FLDs in Madhya Pradesh was appreciably high ranging between 58.3 to 69.1 per cent as compared to fairly low values in Maharashtra 24.1 per cent, which is a clear indication that in the former case which indicates that there exists a strong gap between the generated technology at the research institution their further dissemination at the farmers' fields as compared to the later. Thus, it appears that technology package under rainfed pulses should also include the location specific moisture conservation technologies, so that these crops could perform better under rainfed conditions on farmer's fields. 
Table.1 (a) Impact of full package FLD module on yield and economics of chickpea in Maharashtra

\begin{tabular}{|l|l|c|c|c|c|c|c|c|}
\hline \multicolumn{1}{|c|}{ Year } & Variety & FY & DY & $\begin{array}{c}\text { COC } \\
\text { Farmer }\end{array}$ & $\begin{array}{c}\text { COC } \\
\text { Demo }\end{array}$ & \multicolumn{2}{c|}{ Gross Ret } & $\begin{array}{c}\text { B:C } \\
\text { Femo. }\end{array}$ \\
\hline $\mathbf{2 0 0 9 - 1 0}$ & Digvijay & 16.2 & 20.8 & 11250 & 13420 & 42350 & 59800 & 4.5 \\
& Vijay & 16.3 & 20.4 & 12480 & 13420 & 41370 & 58250 & 4.3 \\
\hline $\mathbf{2 0 1 0 - 1 1}$ & Vijay & 19.5 & 28.02 & 14695 & 17823 & 50908 & 59800 & 3.4 \\
\hline $\mathbf{2 0 1 1 - 1 2}$ & Vijay & 18.7 & 29.46 & 15319 & 17823 & 48860 & 72930 & 4.1 \\
\hline $\mathbf{2 0 1 2 - 1 3}$ & Vijay & 18.6 & 28.04 & 16000 & 18370 & 59680 & 76600 & 4.2 \\
\hline $\mathbf{2 0 1 3 - 1 4}$ & Vijay & 17.2 & 20.3 & 17450 & 19747 & 51480 & 89730 & 4.5 \\
\hline $\mathbf{2 0 1 4 - 1 5}$ & Vijay & 17 & 20 & 17450 & 19500 & 51500 & 60900 & 3.1 \\
\hline & & $\mathbf{1 7 . 6}$ & $\mathbf{2 3 . 9}$ & $\mathbf{1 4 9 4 9}$ & $\mathbf{1 7 1 5 8}$ & $\mathbf{4 9 4 5 0}$ & $\mathbf{6 8 2 8 7}$ & $\mathbf{4 . 0}$ \\
\hline
\end{tabular}

Table.1 (b) Impact of full package FLD module on yield and economics of chickpea in Madhya Pradesh

\begin{tabular}{|c|l|l|l|l|l|l|l|l|}
\hline Year & Variety & \multicolumn{1}{|c|}{ FY } & \multicolumn{1}{|c|}{ DY } & $\begin{array}{c}\text { COC } \\
\text { Farmer }\end{array}$ & $\begin{array}{c}\text { COC } \\
\text { Demo }\end{array}$ & \multicolumn{2}{c|}{ Gross Ret } & $\begin{array}{c}\text { B:C } \\
\text { Demo }\end{array}$ \\
\hline $\mathbf{2 0 0 9}-10$ & JG-130 & 12.5 & 15.7 & 10900 & 9844 & 28933 & 35540 & 3.6 \\
& KAK-2 & 8.6 & 15.2 & 10900 & 10990 & 27520 & 42560 & 3.9 \\
\hline $\mathbf{2 0 1 0}-11$ & JG-130 & 11.2 & 16.5 & 11755 & 9844 & 36960 & 40425 & 4.1 \\
\hline $\mathbf{2 0 1 1 - 1 2}$ & JG-218 & 9.9 & 14.8 & 11670 & 9800 & 32575 & 36354 & 3.7 \\
\hline $\mathbf{2 0 1 2}-13$ & JG-11 & 10.7 & 16.3 & 12844 & 13880 & 32995 & 39306 & 2.8 \\
\hline $\mathbf{2 0 1 3 - 1 4}$ & JG-130 & 9.9 & 14 & 17350 & 16500 & 24000 & 35280 & 2.1 \\
\hline $\mathbf{2 0 1 4 - 1 5}$ & JG-130 & 10.8 & 14.7 & 15600 & 16542 & 30240 & 41160 & 2.5 \\
\hline
\end{tabular}

Table.2 Technological gap, Extension gap and Technological index of the respondents of chickpea FLD in Madhya Pradesh from (2009-10 to 2014-15)

\begin{tabular}{|l|l|l|l|l|l|}
\hline State & Variety & $\begin{array}{l}\text { Potential } \\
\text { Yield }\end{array}$ & $\begin{array}{l}\text { Technologic } \\
\text { al Gap (Py- } \\
\text { Dy }\end{array}$ & $\begin{array}{l}\text { Extension } \\
\text { Gap (Dy- } \\
\text { Fy) }\end{array}$ & $\begin{array}{l}\text { Technological } \\
\text { Index (P-D) / } \\
\text { P*100) }\end{array}$ \\
\hline $\begin{array}{c}\text { Madhya } \\
\text { Pradesh }\end{array}$ & JG-130 & 30 & 17.5 & 3.2 & 58.3 \\
\cline { 2 - 6 } & KAK-2 & 25 & 16.4 & 6.6 & 65.6 \\
\cline { 2 - 6 } & JG-130 & 30 & 18.8 & 5.3 & 62.7 \\
\cline { 2 - 5 } & JG-218 & 32 & 22.1 & 4.9 & 69.1 \\
\hline & JG-11 & 32 & 21.3 & 5.6 & 66.6 \\
\cline { 2 - 6 } & JG-130 & 30 & 20.1 & 4.1 & 67.0 \\
\hline JG-130 & 30 & 19.2 & 3.9 & 64.0 \\
\hline
\end{tabular}


Table.3 Technological gap, Extension gap and Technological index of the respondents of chickpea FLD in Maharashtra (2009-10 to 2014-15)

\begin{tabular}{|l|l|l|l|l|l|}
\hline State & Variety & $\begin{array}{l}\text { Potential } \\
\text { Yield }\end{array}$ & $\begin{array}{l}\text { Technologic } \\
\text { al Gap }(\text { Py- } \\
\text { Dy }\end{array}$ & $\begin{array}{l}\text { Extension } \\
\text { Gap (Dy-Fy) }\end{array}$ & $\begin{array}{l}\text { Technological } \\
\text { Index (P-D) / } \\
\text { P*100) }\end{array}$ \\
\hline \multirow{2}{*}{ Maharashtra } & Digvijay & 28 & 7.2 & 4.6 & 25.7 \\
\cline { 2 - 6 } & Vijay & 32 & 11.6 & 4.1 & 36.3 \\
\hline & Vijay & 32 & 3.98 & 8.52 & 12.4 \\
\hline & Vijay & 32 & 2.54 & 10.76 & 7.9 \\
\hline & Vijay & 32 & 3.96 & 9.44 & 12.4 \\
\hline & Vijay & 32 & 11.7 & 3.1 & 36.6 \\
\hline & Vijay & 32 & 12 & 3 & 37.5 \\
\hline \multirow{2}{*}{ Mean } & & $\mathbf{3 1 . 4}$ & $\mathbf{7 . 6}$ & $\mathbf{6 . 2}$ & $\mathbf{2 4 . 1}$ \\
\hline
\end{tabular}

Fig.1 Annual change in Technical Yield Gap and Technological Index of Both States

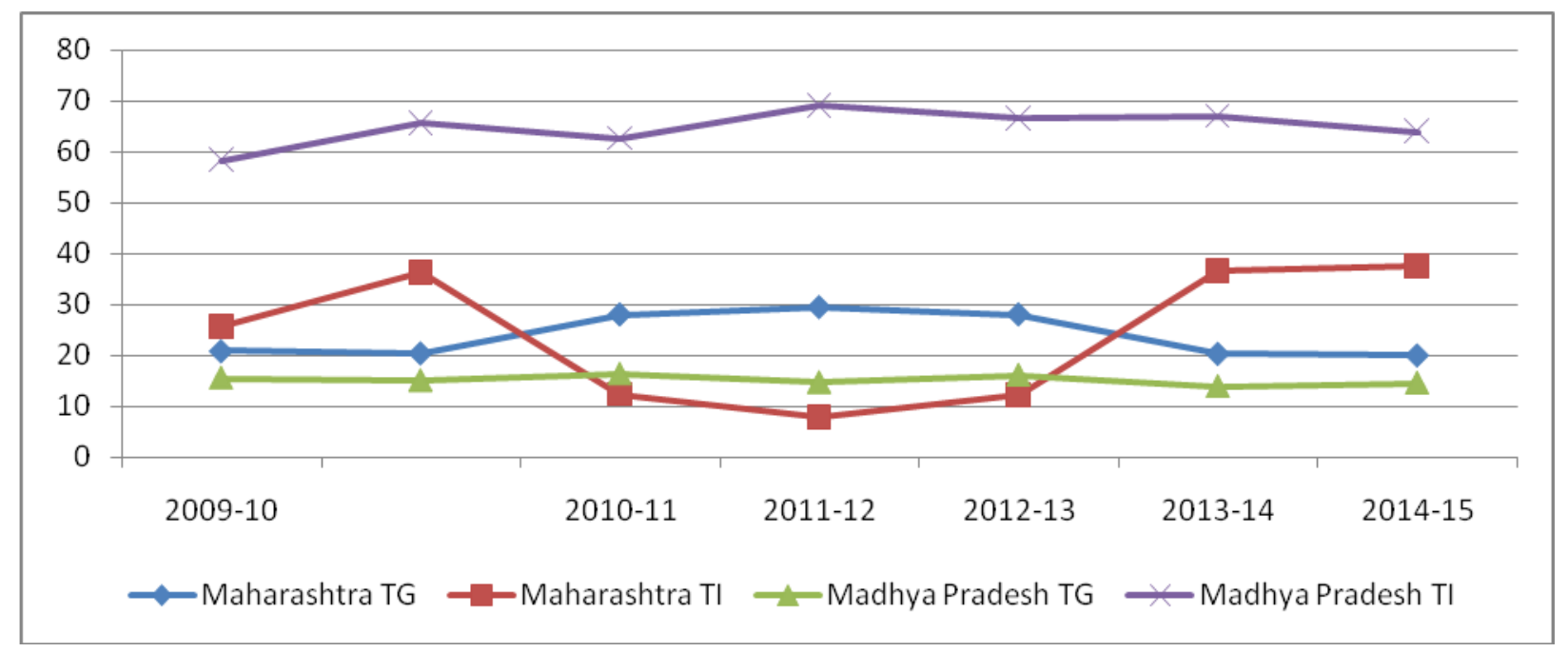

The lower the value of the technology index more is the feasibility of the technology. Similar findings were also reported by Kadian et al., (1997).

\section{Economic analysis of front line demonstrations}

The economic analysis of FLDs as (Table 1a and1b) clearly indicate that the highest gross return of Rs 89,730 and lowest of Rs 58,200 was found in variety Vijay in Maharashtra and the $\mathrm{B}$ : $\mathrm{C}$ ratio varied from 4.3 to 4.5 , whereas in Madhya Pradesh despite changing the varieties the highest gross return was Rs 42,560 and lowest Rs 35,280 and the B: C ratio varied between 2.1 to 3.9. This reflects the inconsistency of market rates in later case due to which the farmers had not fully utilized the technological options to enhance yield. However, the results were far better in both the cases as compared to farmers' practices. Enhanced monetary returns as well as Benefit Cost Ratio (BCR) through improved farm technology have also been reported by various workers (Sagar Chandra, 2004; Choudhary et al., 2009a 2009b). Overall, economic analysis data inferred that transfer 
of improved technology and its adoption in chickpea in both states can substantially enhance the profitability of farmer. The present study conclusively indicated that there exists a wide gap in potential yields, demonstration yields, varietal yield farmers' plot yields under chickpea in both states due to technological extension gaps. The study emphasize upon dissemination of location specific crop management improved technologies imbedded with high yielding varieties (HYVs') to improve pulse productivity profitability. This study also infers that extension functionaries of district particularly ATMA need to focus more on dissemination of proven pulse production farm technologies in pulse production systems to enhance the pulse productivity besides strengthening the irrigation facilities so that resource poor farmers could earn their livelihood on sustainable basis by diversifying their farming systems and help in filling the deficit in pulse production of this region in particular and the country in larger context.

\section{References}

Aggarwal, P K, M J Kropff, K G Cassman and H F M ten Berge (1997): "Simulating Genotypic Strategies for Increasing Rice Yield Potential" in Irrigated Tropical Environments", Field Crops Research, 51: 5-17.

Choudhary, A. K., Yadav, D. S. Singh, A. (2009b). Technological extension yield gaps in oilseeds in $\mathrm{Mi}$ district of Himachal Pradesh. Indian J. Soil Conserv. 37 (3): 224-229.

Kadian, K.S., Sharma, R and Sharma,
A.K.1997. Evaluation of frontline demonstration trials on oilseeds in kangra valley of Himachal Pradesh. Annals of Agriculture Research, 18 (1): 40-43.

Reddy, A.A (2006): "Impact Assessment of Pulses Production Technology", Research Report No 3, Indian Institute of Pulses Research, Kanpur.

Sagar, R.L. Chandra G. (2004). Frontline demonstrations on sesame in west Bengal. Agril. Ext. Rev., 16 (2): 7-10.

Samui, S. K., Maitra, S., Roy, D.K., Mondal, A.K. Saha, D. (2000). Evaluation on frontline demonstration on groundnut. J. Ind. Soc. Coastal Agric. Res., 18 (2): 180-183.

Saxena, K B, D P Srivastava and S B S Tikka (2000): "Breaking Yield Barriers in Pigeon pea through Hybrid Breeding" in M Ali, A N Asthana, Y S Rathore, S N Gurha, S K Chaturvedi and S Gupta (ed.), Advances in Management of Biotic and Abiotic Stresses in Pulse Crops, Indian Institute of Pulses Research, Kanpur, pp 211-19.

Sharma P. K., Kumar, Sanjeev, Ishar A.K., Parkash, S. Jamwal, S.S. (2012). Economic Impact of Front Line Demonstrations (FLD's) in Poonch district of Jammu \& Kashmir. Economic Affairs 57(1): 99-106.

Singh R.P. Status Paper on Pulses. Government of India Ministry of Agriculture (Department of Agriculture \& Cooperation) Directorate of Pulses Development 6th Floor, Vindhyanchal Bhavan Bhopal-462004 (M.P.)

\section{How to cite this article:}

Ishwar Singh, D.S. Tomar, M.V. Mahajan, D.S. Nehte, Lakhan Singh and Singh, H.P. 2018. Impact of Front Line Demonstration on Chickpea to Meet the Deficit Pulse Availability in Malwa Plateau and Central Plateau Region of India. Int.J.Curr.Microbiol.App.Sci. 7(02): 23052311. doi: https://doi.org/10.20546/ijcmas.2018.702.279 